\title{
Javan Rhino (Rhinoceros sondaicus Desmarest 1822) Utilization Distribution and Habitat Selection in Ujung Kulon National Park
}

\author{
Yanto Santosa $^{1 *}$, U Mamat Rahmat ${ }^{2}$, Lilik Budi Prasetyo ${ }^{1}$, Agus Priyono Kartono \\ ${ }^{1}$ Department of Forest Resource Conservation and Ecotourism, Faculty of Forestry, \\ Bogor Agricultural University, IPB Dramaga Campus, PO Box 168, Bogor 16680, Indonesia \\ ${ }^{2}$ Ujung Kulon National Park, Perintis Kemerdekaan No. 51, Labuan Sub-District, \\ Pandeglang District, Banten 42264, Indonesia
}

Received June 18, 2012/Accepted February 20, 2013

\begin{abstract}
Javan rhino (Rhinoceros sondaicus Desmarest 1822) is one of world's rarest endangered species (IUCN 2008). Currently, their distribution is limited to Ujung Kulon National Park (UKNP) of Indonesia. Natural disasters, disease, poaching, encroachment, and competition are threats facing Javan rhino's population, hence creating pockets of habitats outside the UKNP was necessary and should be based on scientific studies of javan rhino utilization distribution and habitat selection in UKNP as the natural habitat. The objectives of the study were to determine the utilization distribution of Javan rhino and its habitat characteristics and determine javan rhino habitat selection within UKNP. The research indicated that Javan rhinos highest use of areas comprised of swampy shrub $(w=2.197)$ and shrub $(w=2.012)$, relatively open habitat $(w=4.233)$, flat area $(w=1.313)$ and slightly sloping areas $(w=1.007)$, lowland $(w=1.346)$, close to river $(w=1.087)$, close to road network $(w=1.395)$, close to coasts/beaches $(w=1.862)$, close to wallowing areas $(w=3.709)$, and close to rumpang $(w=3.783)$. The results suggested that javan rhino showed selection and preferences for its habitat.
\end{abstract}

Keywords: javan rhino, utilization distribution, habitat selection, preferences

*Correspondence author, email: yantohaurjaya@yahoo.co.id, telp.: +62 818-8881-6166

\section{Introduction}

Javan rhino (Rhinoceros sondaicus Desmarest, 1822) is one of the world's rare animal species, which is protected by the Indonesian Government Regulation Number 7 of 1999. The IUCN (International Union for Conservation of Nature and Natural Resources) classifies javan rhino as critically endangered in the red list. Javan rhino is also listed in the Appendix I of CITES (Convention on International Trade in Endangered Species of Wild Fauna and Flora), which is indicative of species with a very limited number in nature and is threatened to be extinct, that any forms of trade are prohibited (Soehartono \& Mardiastuti 2002). Currently, javan rhino thrives only in Ujung Kulon National Park (UKNP) of Indonesia with a relatively small population of less than 44 individuals (Ellis 2010) or a minimum of 35 individuals (TNUK 2011). Javan rhino was previously declared extinct in Vietnam (IRF 2011; WWF 2012).

Javan rhino has been studied with respect to its ecological behaviour (Schenkel \& Schenkel-Hulliger 1969; Hoogerwerf 1970; Sajudin 1984), habitat suitability (Muntasib 2002), and habitat preferences (Rahmat 2007; Chandradewi 2011). However, these studies had been partially conducted both in terms of substance and locations of study.

The survival of javan rhino in UKNP faces various forms of threats. As wildlife with limited distribution, javan rhinos are more susceptible to natural disasters, such as Krakatau explosion, earthquake, and tsunami. In addition, there are increasing human threats from activities such as settlement expansion, illegal cultivation, and forest encroachment. However, the biggest threat to javan rhino is poaching for its horns (Rahmat 2009). One proposed solution is to provide alternative habitat or pockets of habitats located outside UKNP. Therefore, study on the utilization distribution and habitat selection of the javan rhino in UKNP is necessary.

Various statistical models are available to analyse resource selection by animals including linear regression, logistic regression, discriminant function analysis, compositional analysis, and principal component analysis (Morrison et al. 1998; Manly et al. 2002). Such methods generally indicate the presence or absence of a species in an environment in which one or more predictor variables was collected. Other methods use only the presence of species to describe the habitat (Manly et al. 2002). However, a species rarely uses its territory or home range in uniform, but is more likely to use some areas which are central to its activities while other areas are considered transitional (Marzluff et al. 2004).

The relative frequency of resources used by a population or individuals can be described by the utilization distribution (Marzluff et al. 2004). The utilization distribution is a probability density function that quantifies the relative use 
of space (Worton 1989; Haris et al. 1990). Utilization distribution is very often related to the estimators of probabilistic home range describing an area, using frequency of space use, and describing the core areas within the home range (Worton 1989; Haris et al. 1990; Getz \& Wilmers 2004). Marzluff et al. (2004) is the first to relate the probability of animal existence within its home range.

The study is conducted through field observation using satellite images and GIS technology to obtain data on activity distribution or habitat use of javan rhino. The study was intended to predict the relationship between space and habitat selection with determinant variables such as land cover types, slope, altitude, crown cover (Leaf Area Index, LAI), distance from roads, distance from rivers, distance from wallowing areas/wallows, distance from coasts/beaches, and distance from forest gaps (rumpang).

The research objectives are to determine utilization distribution of javan rhino based on indicators of its existence and to determine habitat selection of javan rhino within UKNP. The availability of data and information on javan rhino utilization distribution can be used for in-situ habitat management of javan rhino, as considerations for javan rhino's second habitat outside the UKNP, and asa basis in determining the UKNP zoning.

\section{Methods}

The research was conducted at Ujung Kulon Peninsula of Ujung Kulon National Park covering an area of 33.389 ha and carried out from January 2011 through to April 2012. Utilization distribution and habitat selection of javan rhino were determined based on direct presence of the animal, footprints, faeces, and wallows obtained from field observations and measurements that have been tested (Manly et al. 2002, Sawyer et al. 2009). Habitat variables used in determining the utilization distribution and habitat selection of javan rhino include slope, altitude, distance from roads, distance from rivers, distance from coasts/beaches, distance from wallows, distance from rumpang, and crown cover. The distance between the point of Javan rhino presence to road network, beaches, river, wallows, and rumpangs were determined using the Euclidean distance. Habitat selection of javan rhino was measured using resource selection function (Manly et al. 2002) to predict the probability of a sample unit being used by an animal, as a function of habitat (Sawyer et al. 2009). The significance test was performed using Chi-square $\left(\chi^{2}\right)$ test (Fleis 1981). The measured variables, method of data collection and processing were presented in detail on Table 1.

\section{Results and Discussion}

Relating javan rhino utilization distribution to land cover types Land cover of Ujung Kulon Peninsula areas comprised of 6 types, namely primary dry land forest, secondary dry land forest, secondary mangrove forest, secondary swamp forest, shrubs, and swampy shrubs. The secondary dry land forest had the largest proportion covering about $58.44 \%$ of the total research area, followed by shrubs $24.58 \%$, primary dry land forest $10.35 \%$, secondary mangrove forest $3.25 \%$, swampy shrubs $2.53 \%$ and secondary swamp forest $0.86 \%$. The greatest distribution of javan rhino based on the 180 frequency of presence was found in shrub areas (49.44\%), followed by secondary dry land forest $(42.78 \%)$, swampy shrubs $(5.56 \%)$, and primary dry land forest $(2.22 \%)$ as presented in Figure 1.

Relating javan rhino utilization distribution to NDVI

Table1 Variables measured, data collection and processing methods

\begin{tabular}{|c|c|c|}
\hline Measured variables & $\begin{array}{c}\text { Data collection } \\
\text { methods }\end{array}$ & Data processing methods \\
\hline Location of javan rhino & $\begin{array}{l}\text { Literature study and } \\
\text { field survey }\end{array}$ & $\begin{array}{l}\text { Geographical position of javan rhino was uploaded in a } \\
\text { database file (*.dbf) into ArcGIS } 9.3 \text { and overlaid with } \\
\text { land cover map of UKNP derived from imagery } \\
\text { interpretation from the Ministry of Forestry. Habitat } \\
\text { selection was performed using Chi-square test (Fleis } \\
\text { 1981; Ludwig \& Reynolds 1988; Manly et al.2002; Sawyer } \\
\text { et al.2009) and } N e u(w) \text { selection index (Neu et al. 1974). }\end{array}$ \\
\hline
\end{tabular}

\begin{tabular}{|c|c|c|}
\hline Land cover types & Field survey & Euclidean distance, test of independence $\left(\chi^{2}\right)$ (Gaspersz \\
\hline Slope and altitude & & 1994), Neu index (Neu et al. 1974). \\
\hline Distance from rivers & & \\
\hline Distance from wallows & & \\
\hline Distance from coasts/beaches & & \\
\hline Distance from rumpang & & \\
\hline Distance from road network & & \\
\hline LAI & & \\
\hline
\end{tabular}




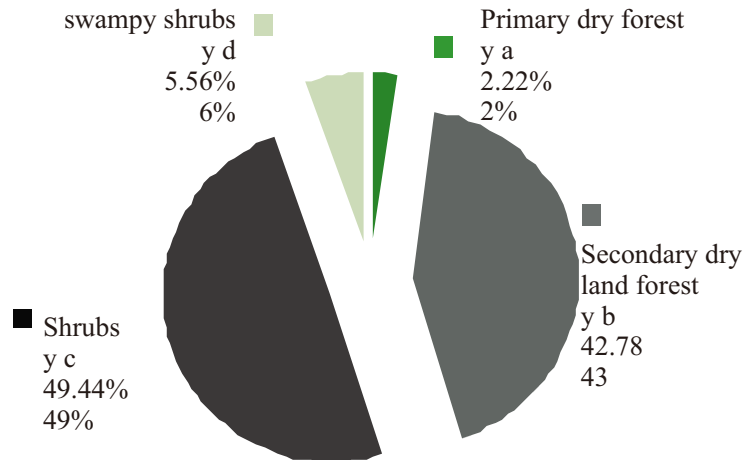

Figure 1 Javan rhinos utilization distribution in various land cover types.

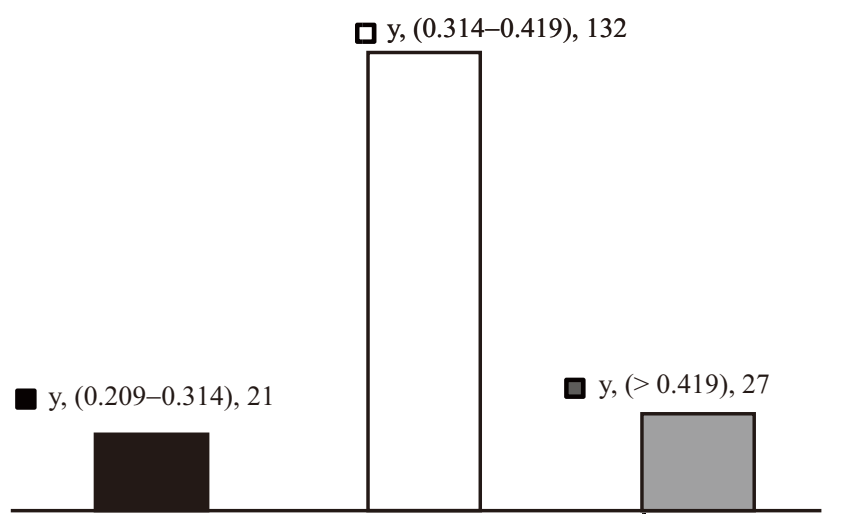

Figure 3 Various ranges of LAI values of Javan rhino utilization distribution.

and LAI The Normalised Difference Vegetation Index (NDVI) value for Ujung Kulon Peninsula and Mount Honje landscapes ranged from 0.7105 to 0.7712 . An NDVI value for an ecological landscape ranged between -1 to 1 . High NDVI values were often occured from vegetation cover with high crown density or well-canopied vegetation.

The measured NDVI values for javan rhino presence were in the range of 0.095-0.540. Based on likert scale of 3 classes, the greatest frequency of javan rhino presence was found within the range of NDVI 0.243-0.391 (81.11\%) with 146 presence, followed by a range of $0.391-0.540(18.33 \%)$ with 33 presence and a range of $0.095-0.243(0.56 \%)$ with 1 presence as presented in Figure 2.

Leaf Area Index (LAI) is the total one-sided area of leaf tissue per unit ground surface area. It is a vegetation characteristic of the canopy of an ecosystem which determines and control canopy water interception, sun radiation coverage, carbon gas exchange, and a key variable in biogeochemical cycles in ecosystems (Breda 2003). According to Lang et al. (1991), LAI could simply be defined as the number of leaf surface area per unit ground surface area and it is a key parameter in ecophysiology, water balance model, and characterization of vegetation and atmosphere interaction.

LAI values were estimated to be in the range of $0.035-$ 6.434. LAI value for rumpangs/for aging site was $0.035-$

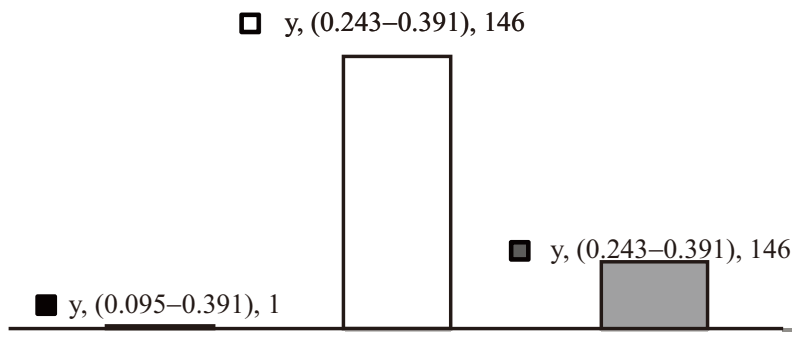

Figure 2 Javan rhino utilization distribution on various NDVI values.

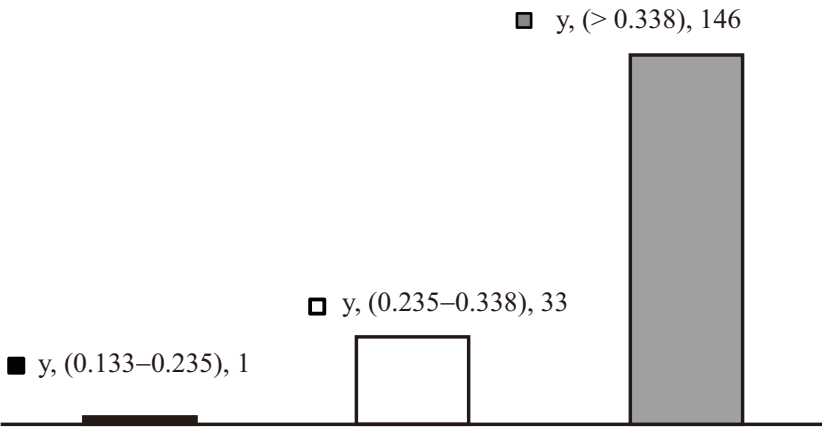

Figure 4 Javan rhino utilization distribution of various LAINDVI regression.

1.121, wallows $0.275-1.677$, bathing site $0.613-1.207$, and defecating site $0.375-6.434$. LAI for javan rhino utilization distribution in Ujung Kulon Peninsula was in the range of 0.209-0.525. Based on likert scale of 3 classes, the greatest frequency of javan rhino presence as shown in Figure 3, was found within the range LAI values of 0.314-0.419 with 132 presence $(73.33 \%)$, followed by the range of $0.419-0.525$ with 27 presence $(15 \%)$ and least on range of $0.209-0.314$ with 21 presence $(11.67 \%)$.

A simple linear regression analysis in this research showed that statistically, NDVI is closely correlated with LAI. This result confirmed with results from previous numerous studies. For example, Xiao et al. (2002) relate LAI and NDVI using linear regression analysis on rice planted field in Jiangning County of China. The regression analysis on LAI and NDVI values on javan rhino presence, resulted in the following equation: $Y=0.0671+0.692 X$ with coefficient of determination $\left(R^{2}\right)$ of $35.2 \%$ and the Pearson coefficient of correlation of $59.3 \%$. The equation indicated that 1 unit increase of NDVI would increase a LAI value of 0.692 .

The utilization distribution of javan rhino based on LAINDVI regression was measured to be in the range of $0.133-$ 0.440 . Based on likert scale of 3 classes, the LAI-NDVI value range $0.133-0.235$ had 1 presence $(0.56 \%)$, range of $0.235-0.338$ had 33 presence (18.54\%), and range of $0.338-$ 


\subsection{0 had 144 presence $(80.90 \%)$, as shown in Figure 4.}

Relating javan rhino utilization distribution to slope The presence of javan rhino based on slope is presented in Figure 5. In general, the division of slope classes had been arranged through the Decree of Minister of Agriculture No. $837 / \mathrm{Kpts} / \mathrm{II} / 1980$ on criteria and procedures to establish protected forest.

Figure 5 showed the greatest presence of javan rhino was on flat area (52.78\%), followed by slightly sloping $(32.22 \%)$, rather steep slope $(12.22 \%)$, and steep slope $(2.78 \%)$ areas. The results showed that javan rhino has preference on areas with flat to rather steep slope area, which is similar to results obtained by Muntasib (2002), Rahmat (2007) and Chandradewi (2011). Javan rhino used flat to slightly sloping areas to fulfil all its necessary survival needs of food, drink, and wallow. Javan rhino big posture would make it difficult for the animal to reach steep slope areas. There were no literatures to date which stated that javan rhino approached and even favoured steep slope areas. Javan rhino would move up to rather steep slope areas (15-25\%) by positioning itself parallel to contour instead of perpendicular.

Relating javan rhino utilization distribution to altitude

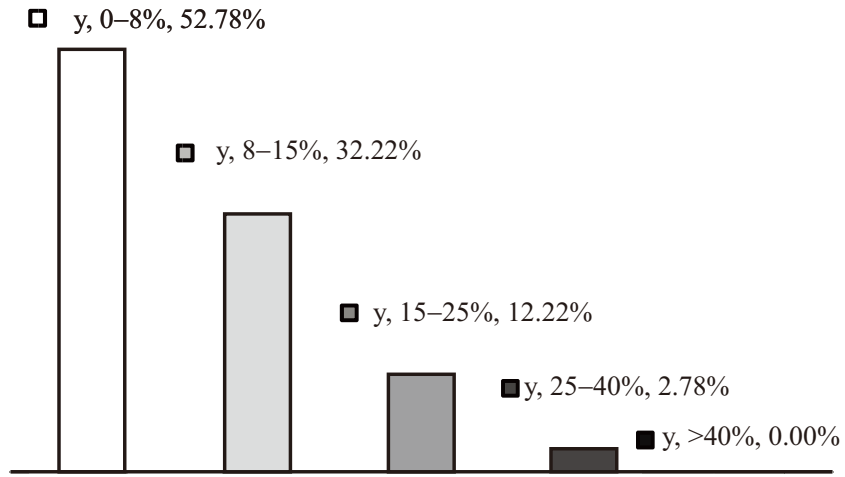

Figure 6 Javan rhino utilization distribution in Ujung Kulon Peninsula based on slope.

ㅁ $\mathrm{y}, 0-1000(\mathrm{~m}), 95.56 \%$

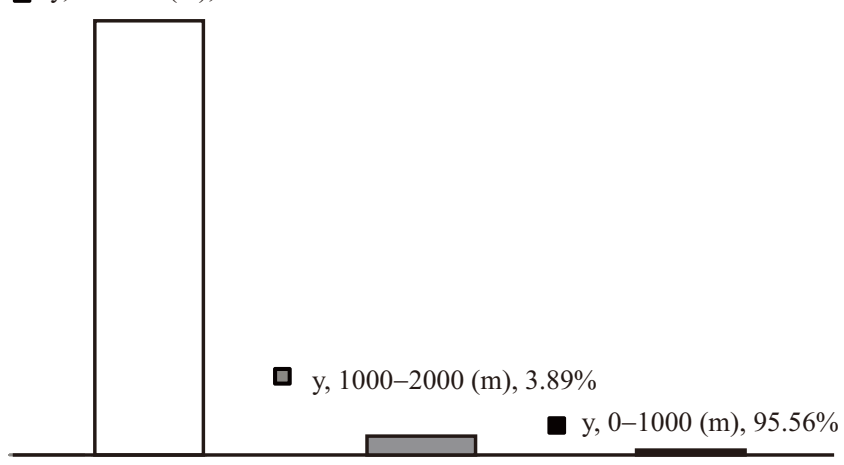

Figure 7 Javan rhino utilization distribution based on distance from rivers in Ujung Kulon Peninsula.
Javan rhino presence based on altitude (Figure 6) ranged between 0-50 $\mathrm{m}$ above sea level (asl) $(92.22 \%$ ), followed by an altitude of 50-100 $\mathrm{m}$ asl (7.22\%), and more than $100 \mathrm{~m}$ asl $(0.56 \%)$.

Relating javan rhino utilization distribution to distance from rivers Water availability in a habitat could be divided into 2 conditions depending on the season. On rainy season, water was evenly distributed all over Ujung Kulon Peninsula area, while in long dry season, water are available only on major rivers such as: Cibandawoh River, Cikeusik River, Citadahan River, Cibunar River, Cijungkulon River, Cicangkok River, Citelang River, Cikarang River, Cigenter River, and major rivers around Handeuleum Islands.

The evenly distribution of water availability throughout Ujung Kulon Peninsula was indicative that water was not a critical limiting factor for javan rhino survival, although it is an important component. Javan rhino use water for drinking, bathing, and wallowing (Schenkel \& SchenkelHulliger 1969; Hoogerwerf 1970; Muntasib 2002; Rahmat 2007).

Javan rhino presence based on distance from rivers was found to be in the range of $0-1000 \mathrm{~m}(95.56 \%)$, followed by a distance range of 1000-2000 $\mathrm{m}(3.89 \%)$ and distance of more than $2000 \mathrm{~m}(0.55 \%)$, as presented in Figure 7.

ㅁ $\mathrm{y}, 0-50$ (m asl), $92.22 \%$

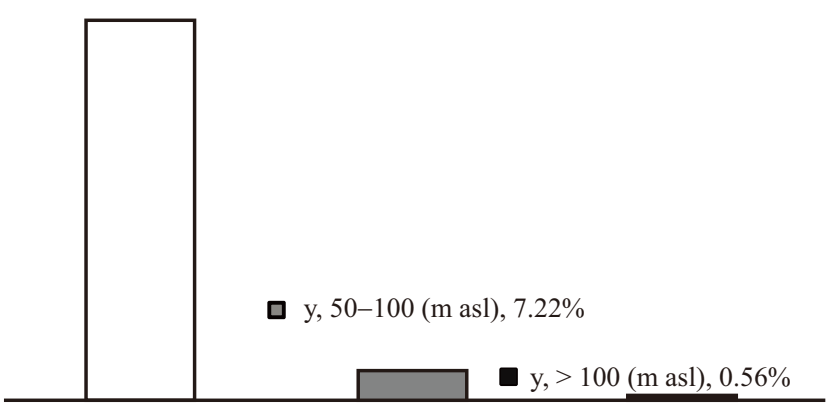

Figure 6 Javan rhino utilization distribution based on various altitude classes in Ujung Kulon Peninsula.

ㅁ $\mathrm{y}, 0-1000(\mathrm{~m}), 83.33 \%$

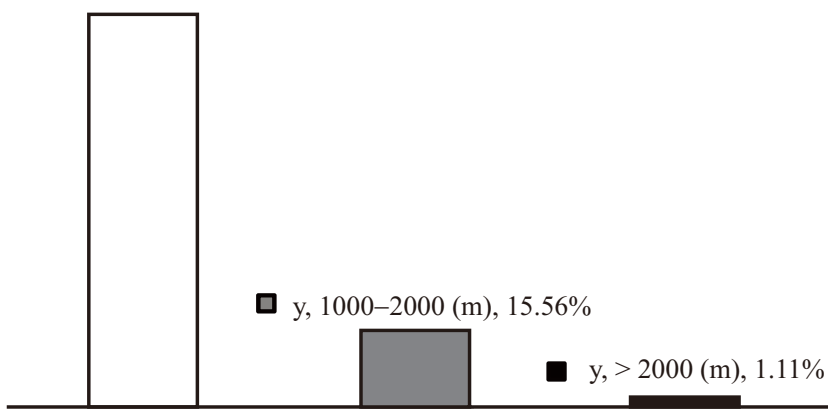

Figure 8 Javan rnıno utilization distribution based on distance from road network in UjungKulon Peninsula. 
Relating javan rhino utilization distribution to road network The presence of javan rhino based on distance from roads was $83.33 \%$ for distance between $0-1,000 \mathrm{~m}$, followed by $15.56 \%$ for distance range of $1,000-2,000 \mathrm{~m}$ $1.11 \%$ for distance over $2,000 \mathrm{~m}$.

Relating javan rhino utilization distribution to coasts/ beaches The presence of javan rhino based on distance from coasts/beaches (Figure 9) indicated that javan rhino demonstrated a high amount of movement on the distance range of $0-1,000 \mathrm{~m}(60.00 \%)$ followed by $1,000-2,000 \mathrm{~m}$ $(24.44 \%)$ and distance of more than 2,000 $\mathrm{m}(15.56 \%)$.

Relating javan rhino utilization distribution to distance from wallows Wallow is one of the physical components of habitat that was essential for the survival of javan rhino. Wallowing for javan rhino, serves the function of self adaptation process toward various environmental condition changes. Besides for wallowing and drinking, wallows also served the function of a place to defecate and urinate. Hoogerwerf (1970) states that wallow is used not only as a place to wallow, but also use as places to drink, defecate, and urinate.

Wallow for javan rhino could also functioned as cleaning agent from dirt and illness, to neutralize body temperature, and to rest. Amman (1985) suggests that the main function of wallowing is to maintain skin moisture, regulate body temperature, and reduce parasites infection rates. Wallowing activities of javan rhino is dependent on water availability, hence is influenced by seasons. During rainy seasons when water was evenly distributed throughout the habitat, and filling in almost all wallowing places, wallowing activities of javan rhino tent to increase. On the contrary, during dry season when there was limited water availability and many wallows were dry, javan rhino would increase bathing activities in large rivers.

Amman (1985) divided wallows into 2 types, the permanent and temporary wallows. Permanent wallows refer to wallows that continuously used throughout the year by one or more javan rhinos in turns. These wallows were usually located close to water flowing areas or rivers that even during dry season the wallows would still be filled with water or at least still wet. Rahmat (2007) states that javan rhino's wallows were often located near water sources and

ㅁy, 0-1000 (m), 60.00\%

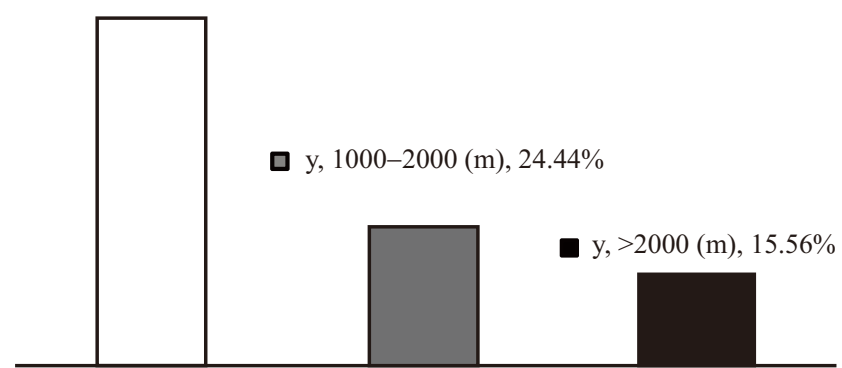

Figure 9 Javan rhino utilization distribution based on distance from coasts/beaches in Ujung Kulon Peninsula. foraging place. Wallows were generally located on relatively hidden and difficult to access areas since such areas were usually densely vegetated with plants such as cangkeuteuk bamboo, rattan, and salak/snake fruits.

Wallows varied in size ranging from length of 2-14 m and width of 2-9 m. Wallow with length of more than $9 \mathrm{~m}$ was found in Cigenter and Citadahan areas. Rahmat (2007) finds a 12-m length wallow at Citadahan block, while this research found a 14-m length wallow in the same block. Presumably, this was the same wallow which had grown in length due to the frequent use by javan rhino.

Javan rhino presence based on distance from wallows (Figure 10) indicated a heavy use of areas with distance 0$1000 \mathrm{~m} \mathrm{(91.11 \% )} \mathrm{followed} \mathrm{by} \mathrm{1,000-2,000} \mathrm{m} \mathrm{(8.33 \% )} \mathrm{and}$ distance of more than $2,000 \mathrm{~m}(0.56 \%)$.

Relating javan rhino utilization distribution to distance from rumpang Rumpang is a relatively open area located in the centre or side of forest. Rumpangs could be created naturally or man-made. Naturally formed rumpangs were usually caused by fallen trees or forest fire, while man-made rumpangs were usually created as a mean of habitat management by cutting several trees on a specific location. There had been several efforts to create rumpangs by cutting langkap (Arenga obtusifolia) both manually (axe) and mechanically (chain saw) followed by planting javan rhino food plants in several areas of UKNP including Blocks of Cibandawoh, Cigenter, Cimayang, Cijengkol and Cikarang.

Based on distance from rumpangs, javan rhino presence was greatest on areas within the distance of $0-1,000 \mathrm{~m}$ (92.22\%) followed by distance of 1,000-2,000 m (6.11\%) and distance of more than $2,000 \mathrm{~m}(1.67 \%)$ as presented in Figure 11.

Javan rhino often used rumpangs as foraging areas, known to local people as "panyampalan". It was clearly observed that javan rhino specifically used rumpangs to forage that such areas could be considered as the "eating place" for javan rhino. Rumpangs or panyampalan were usually overgrown with plant species such as Spanish flag (Lantana camara), bisoro (Ficus hispida), areuy kawao (Agelaea macrophylla), rotan seel (Daemonorops melanochaetis), bangban (Donax cannaeformis), tepus

ㅁ $\mathrm{y}, 0-1000(\mathrm{~m}), 91.11 \%$

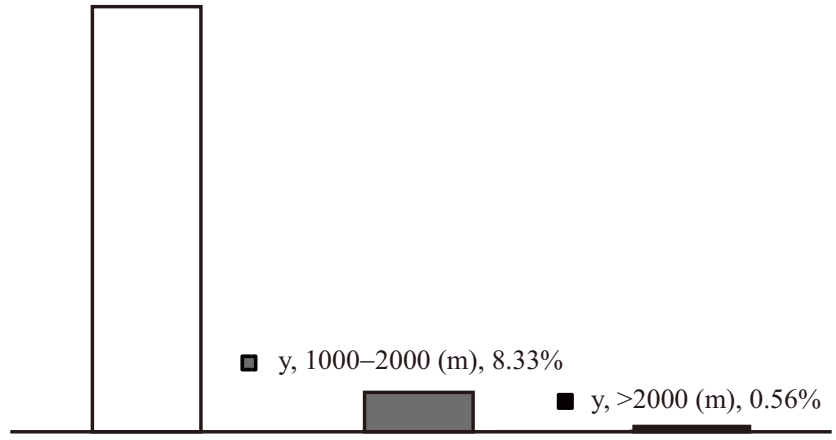

Figure 10 Javan rhino utilization distribution based on distance from wallows in Ujung Kulon Peninsula. 
ㅁ $\mathrm{y}, 0-1000(\mathrm{~m}), 92.22 \%$

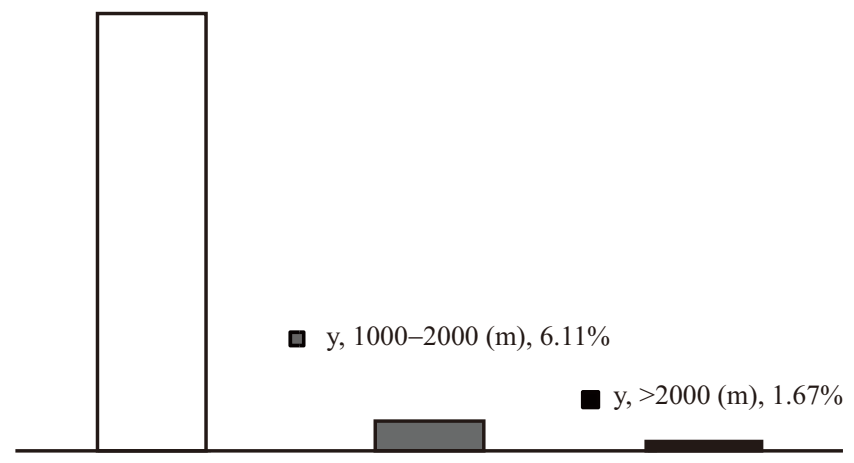

Figure 10 Javan rhino utilization distribution based on distance from rumpangs in Ujung Kulon Peninsula.

(Amomum coccineum), sulangkar (Leea sambucina) and various undergrowth which provide forage sources.

Habitat selection by javan rhino Chi Square $\left(\chi^{2}\right)$ analysis showed that significant correlations between javan rhino utilization distribution and land cover types, slope, altitude, distance from roads, distance from rivers, distance from coasts/beaches, distance from wallows, distance from rumpangs, and crown cover (LAI) $(p<0.05)$. All of these indicated javan rhino habitat selection.

Calculation of selection index $(w)$ demonstrated that javan rhino preferred swampy shrubs $(w=2.197)$ and shrubs $(w=2.012)$. Based on crown cover (LAI), javan rhino preferred relatively open areas $(w=4.233)$, flat slopes $(w=$ $1.313)$ and slightly sloping areas $(w=1.007)$, lowlands $(w=$ $1.346)$, close to river areas $(w=1.087)$, close to road network $(w=1.395)$, close to coasts/beaches $(w=1.862)$, close to wallows $(w=3.709)$ and close to rumpangs $(w=3.783)$.

As a browser, javan rhino required plants shoots. Plants shoots were more abundant in secondary forest and more open areas such as shrubs and rumpangs rather than in primary forest. Shrubs and swampy shrubs provided javan rhino with various undergrowth and seedlings. Field observation indicated that javan rhino feed more undergrowth such as areuy-areuyan, as stated by Rahmat et al. (2008).

In general, javan rhino often carried out its activities on relatively open areas, which was not grassland. These relatively open areas were used more frequently as foraging area (rumpangs). Such rumpangs provided an abundant food sources for the rhinos, such as tepus, cente, sulangkar, segel, ciciap, bisoro, rattan, areuy palungpung, areuy kuku heulang, areuy jeunjing kulit, areuy capituher, and areuy leuksa. More than $75 \%$ of Javan rhinos used areas with dense crown cover to perform specific activities such as wallowing, bathing, and defecating. As stated by Rahmat (2007) and Chandradewi (2011), defecating, bathing, and wallowing activities were more frequently carried out by javan rhino in relatively sheltered areas, such as under vegetation of langkap, salak, cangkeuteuk, and kaman.

Based on altitude, javan rhino preferred lowland over highland areas, particularly when the slope to the highland was steep. Nevertheless, javan rhinos were never found on high flat lands. Furthermore, javan rhino occupied greater lowland areas due to larger food and water availability. Therefore, altitude was not a limiting factor for javan rhino utilization distribution. This was evident by the findings of javan rhinos in Mt. Selamet on 1867, Mt. Tangkuban Perahu on 1870, Mt. Gede Pangrango on 1880, Mt. Papandayan on 1881, and Mt. Ciremai on 1897 (Hoogerwerf 1970).

Javan rhino preferred areas closed to rivers, wallows, and rumpangs as its niche since the advantage of inhabiting such areas would be higher than the loss (Odum 1993). The results of the study were similar to the works of Aman (1985), Schenkel \& Schenkel-Hulliger (1969), Hoogerwerf (1970), and Rahmat (2007). Thus, javan rhino also developed behaviour to seek for water sources, particularly for optimal foraging behaviour to minimize the losses that might incur (Ezhilmathi 2010). Javan rhino tent to prefer habitats close to human roads since such areas provide abundant plants shoots due to slashing activities by people passing through. This result was different to Muntasib (2002) who state that javan rhino do not prefer areas close to roads or pathways, hence tent to avoid such areas.

Based on distance from coasts/beaches, javan rhino preferred habitats close to coasts/beaches, related to their requirements of mineral salts which were available in more quantity around coasts/beaches (Rahmat 2007). Rahmat (2007) states that coasts/beaches are overgrown with undergrowth making them relatively open areas. Similar statement was also given by Schenkel and SchenkelHulliger (1969) and Amman (1985). Leaves of javan rhinos' food plants along coastal areas contained salt layer due to the adsorption of mineral salts from sea water blown in land (Rahmat 2007).

\section{Conclusion}

In terms of utilization distribution, javan rhino used several land covers consisted of shrubs (49.44\%), secondary dry land forest $(42.78 \%)$, swampy shrubs $(5.56 \%)$ and primary dry land forest $(2.22 \%)$, flat area $(52.78 \%)$ to slightly sloping (32.22\%) areas, lowland habitat (92.22\%), relatively open habitat $(80.90 \%)$, habitat close to rivers $(95.56 \%)$, wallows $(91.11 \%)$, human roads $(83.33 \%)$, coasts/beaches $(60.00 \%)$, and rumpangs $(92.22 \%)$. These indicated that javan rhino selected and/or had preferences for its habitat characteristics.

\section{Recommendation}

The results of this research provide some considerations into the management of javan rhino's habitat and population, as well as the National Park's zoning. Furthermore, the information could be used in formulating the criteria for Javan rhino's second habitat outside their natural habitat, and in developing packages of special interest tourism (ecotourism) activities.

\section{References}

Amman H. 1985. Contribution to the ecology and sociology of the javan rhinoceros (Rhinoceros sondaicus Desm. 1822) [dissertation]. Basel: Naturwissenschaftlichen Fakultat, der Universitat 
Basel.

Breda NJJ. 2003. Ground based measurements of leaf area index: a review of methods, instruments and current controversies. Journal of Experimental Botany 54:2403-2417. http://dx.doi.org/10.1093/jxb/erg263.

Chandradewi. 2011. Perilaku berkubang dan tipologi kubangan badak jawa (Rhinoceros Sondaicus) di Taman Nasional Ujung Kulon [thesis]. Bogor: Graduate School, Bogor Agricultural University.

Ellis S. 2010. Loss of a second critically endangered javan rhino points to dire need for conservation action. Journal of The Rhino Print (Newsletter of the Asian Rhino Project) 8 (2010): 3-4.

Ezhilmathi S. 2010. Foraging behaviour of the microchiropteran bat, Hipposideros ater on chosen insect pests. Journal of Biopesticides 3(1 Special Issue): $68-73$.

Fleis JL. 1981. Statistical Methods for Rates and Proportions. Second Edition. New York: John Wiley \& Sons.

Gaspersz V. 1994. Metode Perancangan Percobaan untuk Ilmu-Ilmu Pertanian, Ilmu-Ilmu Teknik Biologi. Bandung: Armico.

Getz WM, Wilmers CC. 2004. A local nearest neighbor convex hull construction of homeranges and utilization distributions. Ecography 27:489-505. http://dx.doi. org/10.1111/j.0906-7590.2004.03835.x.

Haris S, Cresswell WJ, Forde PG, Trewhella WJ, Woolard T, Wray S. 1990. Home range analysis using radio tracking data a review of problems and techniques particularly as applied to the study of mammals. Mammal review 20(2/3):97-123.

Hoogerwerf A. 1970. Udjung Kulon: The land of the last Javan Rhinoceros. E.J. Brill Leiden. pp 286-296.

[IRF] International Rhino Foundation. 2011. Javan rhino update June 2011. Journal of The Rhino Print (Newsletter of the Asian Rhino Project)Vol.2011:2-4.

Lang ARG, McMurtrie RE, Benson ML. 1991. Validity of surface area indices of Pinus radiate estimated from transmittance of the sun's beam. Agricultural and Forest Meteorology 37:229-243.

Ludwig JA, Reynolds JF. 1988. Statistical Ecology. New York: John Wiley \& Sons.

Manly BF, McDonald L, Thomas DL, McDonald T, Erickson W. 2002. Resource Selection by Animals: Statistical Design and Analysis for Field Studies. Second Edition. Boston, Massachusetts: Kluwer Academic Publishers. http://dx.doi.org/10.3724/SP.J.1227.2012.00191.
Marzluff JM, Millspaugh JJ, Hurvitz P, Handcock MS. 2004. Relating resources to a probabilistic measure of space use: forest fragments and steller's jays. Ecology 85(5):1411-1427. http://dx.doi.org/10.1890/03-0114.

Morrison ML, Marcot BG, Mannan RW. 1998. Wildlife Habitat Relationships: Concepts and Applications, $2^{\text {nd }}$ $E d$. Wisconsin: University of Wisconsin Press.

Muntasib EKSH. 2002. Penggunaan ruang habitat oleh badak jawa (Rhinoceros sondaicus Desmarest 1822) di Taman Nasional Ujung Kulon [dissertation]. Bogor: Graduate School, Bogor Agricultural University.

Neu CW, Byers CR, Peek JM. 1974. A technique for analysis of utilization-availability data. Journal of Wildlife Management 38:541-545. http://dx.doi.org/10.2307/ $\underline{3800887 .}$

Odum EP. 1993. Dasar-dasar Ekologi. Edisi ketiga. Yogyakarta: Gadjah Mada University Press.

Rahmat UM. 2007. Analisis tipologi habitat preferensial badak jawa (Rhinoceros sondaicus Desmarest 1822) di Taman Nasional Ujung Kulon [thesis]. Bogor: Graduate School, Bogor Agricultural University.

Rahmat UM, Santosa Y, Kartono AP. 2008. Habitat preference analysis of javan rhino (Rhinoceros sondaicus Desmarest 1822) in Ujung Kulon National Park. Jurnal Manajemen Hutan Tropika 14(3):115124.

Rahmat UM. 2009. Population genetics of javan rhino (Rhinoceros sondaicus Desmarest 1822) and it's conservation strategy. Jurnal Manajemen Hutan Tropika 15(2):83-90.

Rich PM, Wood J, Vieglais DA,Burek K, Webb N. 1998. Hemiview User Manual. Cambridge UK: Delta-T Devices Ltd. http://dx.doi.org/10.1016/0168-1923(86) 90033-X.

Sadjudin HR. 1984. Studi Perilaku dan Populasi Badak Jawa (Rhinoceros sondaicus Desm. 1822) di Ujung Kulon. Jakarta: Fakultas Biologi Universitas Nasional.

Sawyer H, Nielson R, Hicks. 2009. Distribution and Habitat Selection Pattern of Mountain Sheep in the Laramie Range. Wyoming: Western Ecosystems Technology. Inc.

Schenkel R, Schenkel-Hulliger L. 1969. The javan rhinoceros (Rhinoceros sondaicus Desm. 1822) in Udjung Kulon Nature Reserve, its ecology and behavior. Field Study 1967 and 1968. Acta Tropica Separatum 26(2):98-133.

Soehartono T, Mardiastuti A. 2002. CITES Implementation in Indonesia. Jakarta: Nagao Natural Environment Foundation. 
[TNUK] Taman Nasional Ujung Kulon. 2011. Laporan Inventarisasi Badak Jawa (Rhinoceros sondaicus Desmarest, 1822) di Taman Nasional Ujung Kulon. Labuan: Taman Nasional Ujung Kulon.

Worton NJ. 1989. Kernel methods for estimating the utilization distribution in home range studies. Ecology 70(1):164-168. http://dx.doi.org/10.2307/ 1938423.
[WWF] World Wide Fund for Nature. 2012. Javan rhino extinct in Vietnam. Journal Newsletter of $W W F$ Singapore. Vol:5

Xiao X et al. 2002. Quantitative relationships between field measured leaf area index and vegetation index derived from vegetation images for paddy rice fields. International Journal Remote Sensing 23:3595-3604. http://dx.doi. org/10.1080/01431160110115799. 